\title{
Selective Phase Transformation Behavior of Titanium-bearing Electric Furnace Molten Slag during the Molten NaOH Treatment Process
}

\author{
Yang LI, Hai-yang YU, Zuo-tai ZHANG, Mei ZHANG and Min GUO* \\ State Key Laboratory of Advanced Metallurgy, School of Metallurgical and Ecological Engineering, University of Science and \\ Technology Beijing, No. 30, Xueyuan Road, Beijing, 100083 P. R. China.
}

(Received on June 30, 2014; accepted on September 17, 2014)

\begin{abstract}
In this paper, selective phase transformation for titanium-bearing phase (Ti-bearing phase) and impurity phase in titanium-bearing electric arc furnace molten slag (Ti-bearing EAF slag) was effectively realized during the molten $\mathrm{NaOH}$ treatment process. The phase transformation mechanism based on thermodynamic calculation was investigated in detail by $X$-ray diffraction, $X$-ray photoelectron spectroscopy and Raman spectrum. It is indicated that the Ti-bearing phases in Ti-bearing EAF slag such as anosovite solid solution and $\mathrm{Mg}_{2} \mathrm{TiO}_{4}$ can be easily converted to $\mathrm{Na}_{2} \mathrm{TiO}_{3}$ with $\mathrm{NaCl}$-type crystal structure, whilst the main impurity phase such as $\mathrm{MgAl}_{2} \mathrm{O}_{4}$ was apt to be decomposed by molten $\mathrm{NaOH}$ to form $\mathrm{NaAlO}_{2}$ and $\mathrm{MgO}$. In addition, with increasing of roasting temperature and time, as well as decreasing of Ti-bearing EAF slag/ $\mathrm{NaOH}$ mass ratio $\left(\mathrm{R}_{\text {slag/NaOH}}\right)$, the formed $\mathrm{Na}_{2} \mathrm{TiO}_{3}$ could be partly changed to $\mathrm{NaMO}_{2}(\mathrm{M}=\mathrm{Mg}$, Ti, Fe) with $\alpha-\mathrm{NaFeO}_{2}$-type crystal structure, due to the coexisting metal ions like $\mathrm{Mg}^{2+}$ and $\mathrm{Fe}^{3+}$ in the slag be doped into or even substituted the $\mathrm{Ti}$ atoms of $\mathrm{Na}_{2} \mathrm{TiO}_{3}$ to form $\mathrm{NaMO}_{2}(\mathrm{M}=\mathrm{Ti}, \mathrm{Fe}, \mathrm{Mg}$ ).
\end{abstract}

KEY WORDS: Ti-bearing electric arc furnace molten slag; molten $\mathrm{NaOH}$ treatment; phase transformation; thermodynamic; crystal structure.

\section{Introduction}

Ti-bearing slags such as Ti-bearing blast furnace slag (Tibearing BF slag) and Ti-bearing electric arc furnace molten slag (Ti-bearing EAF slag) etc., are considered as valuable secondary resources in China due to their relatively higher $\mathrm{TiO}_{2}$ contents. Since the Ti-bearing slags are produced from various raw ores by using different treating processes, the main chemical compositions and the phase structure of these slags are basically different. Therefore, how to extract titanium efficiently from the Ti-bearing slags has been attracted much attention, and various approaches have been utilized including acid process, ${ }^{1-3)}$ alkali fusion process, ${ }^{4,5)}$ carbonization and chlorination process, ${ }^{6)}$ selective crystallization process. ${ }^{7-11)}$ Comparing these methods, the alkali fusion process shows obvious advantage such as unrestricted raw slag materials, and easy recycling of alkali, etc. More importantly, after alkali fusion process, the Ti-bearing phases can be selectively separated from other impurity phases by only water leaching process based on the different water solubility of formed sodium salts instead of complicate dressing method.

However, no matter which Ti-bearing slags were used during the alkali fusion process, the attention of researchers was mainly focused on the extraction efficiency of titanium

* Corresponding author: E-mail: guomin@ustb.edu.cn DOI: http://dx.doi.org/10.2355/isijinternational.55.134 and the decomposition kinetics of Ti-bearing slags in different alkali systems. None of the efforts have been taken on phase transformation mechanism for titanium and other elements in slags. Zhang et al. ${ }^{12)}$ studied the decomposition behavior of Ti-bearing slag in $\mathrm{NaOH}$ solution at $493 \mathrm{~K}$ for $4 \mathrm{~h}$, and indicated that the hydrothermal product obtained under optimal conditions was $\mathrm{Na}_{4} \mathrm{Ti}_{3} \mathrm{O}_{8}$. Scott Middlemas et al. ${ }^{13)}$ believed that the Ti-bearing phases in Ti-bearing slag could react with molten $\mathrm{NaOH}$ at $773 \mathrm{~K}$ for $4 \mathrm{~h}$ to form $\mathrm{Na}_{2} \mathrm{TiO}_{3}$. Han et al. ${ }^{5)}$ also considered that Ti-bearing slag reacted with molten $\mathrm{NaOH}$ yielded only one kind of sodium titanate $\left(\mathrm{Na}_{2} \mathrm{TiO}_{3}\right)$. In fact, it should be noted that the titania could react with molten $\mathrm{NaOH}$ to form various sodium salts. ${ }^{14-17)}$ However, the phase transformation mechanism of the Ti-bearing phases was not clear, especially the influence of metal ions such as $\mathrm{Fe}^{3+}, \mathrm{Al}^{3+}, \mathrm{Mg}^{2+}$, etc. coexisting in the slags on the formation of Ti-bearing phases were seldom been investigated.

In this paper, Ti-bearing EAF slag was used as raw material to investigate the transformation mechanism of the Tibearing phases and impurity phases during the molten $\mathrm{NaOH}$ treatment process. The phase transformation mechanism was studied in detail based on thermodynamic calculation and crystal structure analysis. This paper may provide some essential thermodynamic information for Ti-bearing slags or other Ti-bearing materials in the molten $\mathrm{NaOH}$ system, and would also give a reference to comprehensive utilization of titanium resource treated by molten $\mathrm{NaOH}$ 
treatment process.

\section{Experimental}

\subsection{Materials and Characterization}

All the chemical reagents employed were analytical grade (Sinopharm Chemical Reagent Co. Ltd) and the distilled water was used throughout the experiment. The Ti-bearing EAF slag samples were provided by Panzhihua Steel Company (Sichuan Province, China), which were obtained from vanadium-titanium magnetite concentrate through direct reduction reaction by rotary hearth furnace and smelting separation by electric furnace. The main chemical compositions of the slag were analyzed by inductively coupled plasma optical emission spectroscopy (ICP-OES, TELEDYNE Leeman Labs) and listed in Table 1. The phase structure of the slag was investigated by X-ray diffraction using $\mathrm{Cu} \mathrm{K} \alpha$ radiation $(\lambda=0.154056 \mathrm{~nm})$ with $40 \mathrm{kV}, 200 \mathrm{~mA}$ and a speed of $10 \%$ min (XRD, M21X, MAC SCIENCE Co. Ltd, Japan). The results shown in Fig. 1 indicated that the Ti-bearing phases of the slag were $\mathrm{MgTi}_{2} \mathrm{O}_{5}, \mathrm{Ti}_{3} \mathrm{O}_{5}$ and $\mathrm{Mg}_{2} \mathrm{TiO}_{4}$, while the main impurity phases were $\mathrm{MgAl}_{2} \mathrm{O}_{4}$ and amorphous $\mathrm{CaSiO}_{3}$. The valences of transition elements were analyzed by X-ray photoelectron spectroscopy (XPS, Al K $\alpha$, AXIS ULTRA), in which C1s binding energy value $(284.8 \mathrm{eV})$ was chosen as standard for baseline correction and baseline subtraction method was Shirley-type. The XPS spectrum of Ti in Ti-bearing EAF slag was shown in Fig. 2. It is shown that about $15 \% \mathrm{Ti}^{3+}$ and $85 \% \mathrm{Ti}^{4+}$ coexisted in the slag, suggesting that the existence form of titanium element might be $\mathrm{Ti}_{3} \mathrm{O}_{5}$ or $\mathrm{Ti}_{2} \mathrm{O}_{3}$ anosovite solid solutions in the slag.

Measurements of Raman spectra were performed on a laser confocal Raman spectrometer (JY-HR800, Jobin Yvon). A blue line $(514 \mathrm{~nm})$ of the laser was taken as the excitation source.

Artificially synthesized $\mathrm{MgTi}_{2} \mathrm{O}_{5}$ was prepared by roast-

Table 1. Main chemical compositions of the Ti-bearing EAF slag (mass\%).

\begin{tabular}{ccccccc}
\hline Composition & $\mathrm{TiO}_{2}$ & $\mathrm{Al}_{2} \mathrm{O}_{3}$ & $\mathrm{MgO}$ & $\mathrm{SiO}_{2}$ & $\mathrm{CaO}$ & $\mathrm{Fe}_{2} \mathrm{O}_{3}$ \\
\hline Content & 50.9 & 19.4 & 12.9 & 8.0 & 5.4 & 2.9 \\
\hline
\end{tabular}

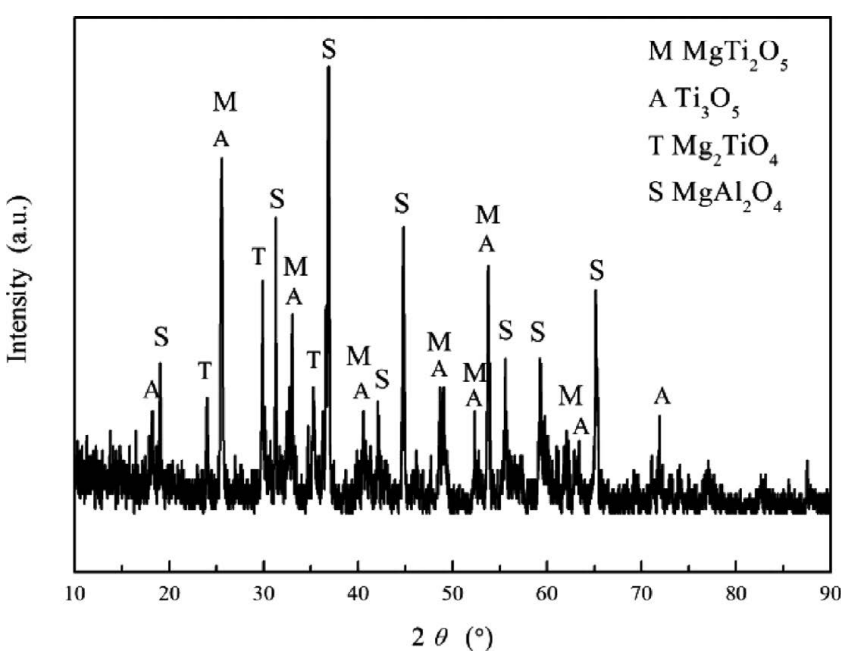

Fig. 1. XRD pattern of the Ti-bearing EAF slag. ing $\mathrm{TiO}_{2}$ (anatase, analytical reagent) with $\mathrm{MgO}$ at $1873 \mathrm{~K}$ for $3 \mathrm{~h}$ with $\mathrm{TiO}_{2} / \mathrm{MgO}$ molar ratio at 2:1.

\subsection{The Concrete Process of Extracting $\mathrm{TiO}_{2}$ from Ti- bearing EAF Slag}

Figure 3 illustrated the general flow sheet of whole extraction process of $\mathrm{TiO}_{2}$ from Ti-bearing EAF slag, and the detailed procedure were described as follows. ${ }^{18)}$ It should be noted that this paper was mainly focus on the molten $\mathrm{NaOH}$ treatment process to elucidate the Ti-bearing EAF slag phase transformation mechanism clearly.

Firstly, $10 \mathrm{~g}$ Ti-bearing EAF slag was ground to about 120 mesh and mixed with $\mathrm{NaOH}$ homogeneously at different mass ratios in a nickel crucible. Then, the nickel crucible was placed into a muffle furnace when the temperature reached a preset value, holding for a required time with free

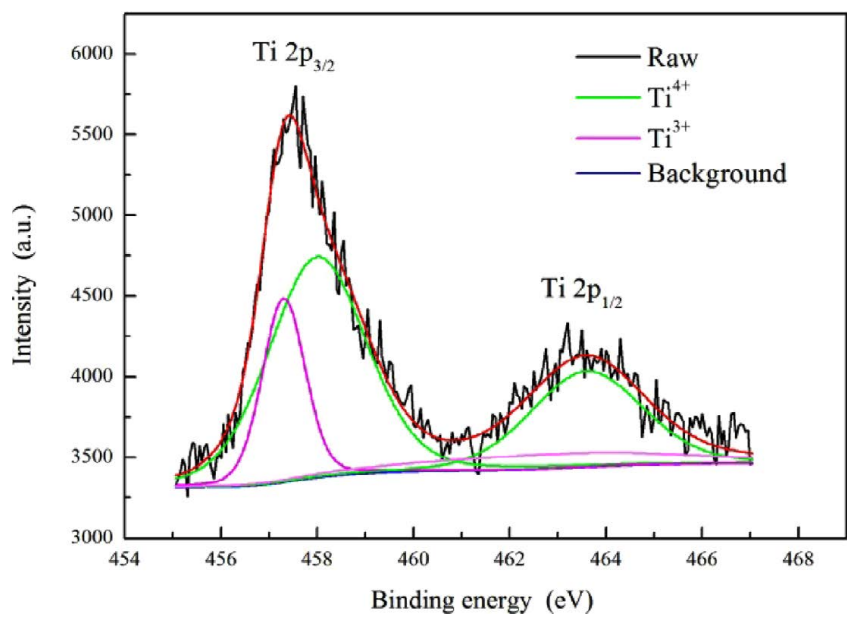

Fig. 2. XPS spectrum of $\mathrm{Ti}$ in the Ti-bearing EAF slag. (Online version in color.)

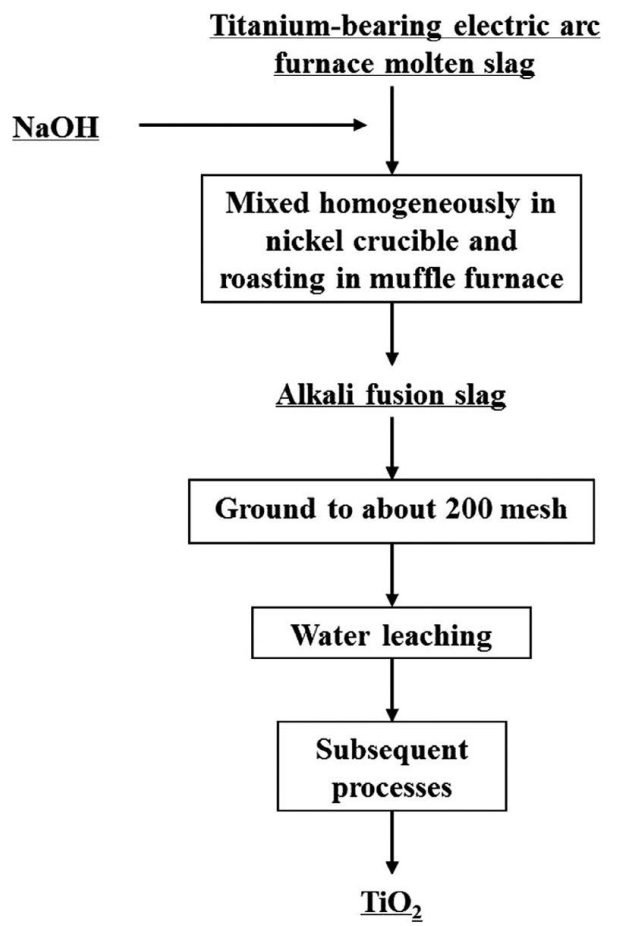

Fig. 3. Schematic flow diagram of extracting $\mathrm{TiO}_{2}$ from Ti-bearing EAF slag. 
access to air. After the molten $\mathrm{NaOH}$ treatment process, the nickel crucible was taken out rapidly and then cooled at room temperature. The obtained slag was called alkali fusion slag. For phase analysis, the alkali fusion slag was ground to about 200 mesh rapidly.

Secondly, as for hydrolysis reaction process, $3 \mathrm{~g}$ ground alkali fusion slag was dissolved in distilled water with electromagnetic stirring for $1 \mathrm{~h}$. The sodium salts such as $\mathrm{Na}_{2} \mathrm{SiO}_{3}$ and $\mathrm{NaAlO}_{2}$ formed in the alkali fusion slag were dissolved in water while the insoluble sodium titanate salts also formed in the alkali fusion slag were separated from the solution by filtration.

Finally, the obtained residue was mixed with $\mathrm{HCl}$ solution and refluxed at $373 \mathrm{~K}$ for $6 \mathrm{~h}$ to perform acidolysis reaction to get metatitanic acid. Then, the samples were calcined in the muffle furnace at $773 \mathrm{~K}$ for $1 \mathrm{~h}$ to obtain $\mathrm{TiO}_{2}$.

\section{Results and Discussion}

\subsection{Thermodynamic Analysis}

When the Ti-bearing EAF slag was mixed with $\mathrm{NaOH}$ and roasted at different temperatures in muffle furnace under atmospheric condition, the related reactions could be described as follows:

$$
\begin{array}{r}
\frac{1}{4} \mathrm{MgTi}_{2} \mathrm{O}_{5}+\mathrm{NaOH}=\frac{1}{2} \mathrm{Na}_{2} \mathrm{TiO}_{3}+\frac{1}{4} \mathrm{MgO}+\frac{1}{2} \mathrm{H}_{2} \mathrm{O} \\
\frac{1}{6} \mathrm{Ti}_{3} \mathrm{O}_{5}+\mathrm{NaOH}+\frac{1}{12} \mathrm{O}_{2}=\frac{1}{2} \mathrm{Na}_{2} \mathrm{TiO}_{3}+\frac{1}{2} \mathrm{H}_{2} \mathrm{O} \\
\frac{1}{2} \mathrm{Mg}_{2} \mathrm{TiO}_{4}+\mathrm{NaOH}=\frac{1}{2} \mathrm{Na}_{2} \mathrm{TiO}_{3}+\mathrm{MgO}+\frac{1}{2} \mathrm{H}_{2} \mathrm{O} \ldots . \\
\frac{1}{2} \mathrm{CaSiO}_{3}+\mathrm{NaOH}=\frac{1}{2} \mathrm{Na}_{2} \mathrm{SiO}_{3}+\frac{1}{2} \mathrm{CaO}+\mathrm{H}_{2} \mathrm{O} \\
\frac{1}{2} \mathrm{MgAl}_{2} \mathrm{O}_{4}+\mathrm{NaOH}=\mathrm{NaAlO}_{2}+\frac{1}{2} \mathrm{MgO}+\frac{1}{2} \mathrm{H}_{2} \mathrm{O} \ldots .
\end{array}
$$

Therefore, the standard Gibbs free energy change $\left(\Delta G^{\circ}\right)$ of the above reactions can be calculated according to Eq. (6).

$$
\begin{aligned}
\Delta G_{T}^{\circ}= & \Delta H_{T}^{\circ}-T \Delta S_{T}^{\circ} \\
= & \Delta H_{298}^{\circ}-T \Delta S_{298}^{\circ}+\int_{298}^{T_{1}} \Delta C_{p} d T+\int_{T_{1}}^{T_{2}} \Delta C_{p}^{\prime} d T \\
& -T_{1} \int_{298}^{T_{1}} \frac{\Delta C_{p}}{T} d T-T_{2} \int_{T_{1}}^{T_{2}} \frac{\Delta C_{p}^{\prime}}{T} d T
\end{aligned}
$$

Where $\Delta G^{\circ}$ is the standard Gibbs free energy change, $\mathrm{J} / \mathrm{mol}$, $\Delta H^{\circ}$ is the standard enthalpy change, $\mathrm{J} / \mathrm{mol}, \Delta S^{\circ}$ is the standard entropy change, $\mathrm{J} /(\mathrm{mol} \mathrm{K}), C_{p}$ is the specific heat capacity at constant pressure, $\mathrm{J} /(\mathrm{mol} \mathrm{K})$. Thereinto, $\Delta H_{298}^{\circ}$, $S_{298}^{\circ}$ and $C_{p}$ could be obtained from the FactPS database of FactSage 6.3 software, respectively, and the related values were listed in Table A1. Figure 4 gave the variation trend of $\Delta G^{\circ}$ ranging from $573 \mathrm{~K}$ to $1173 \mathrm{~K}$. It is shown that the $\Delta G^{\circ}$ of all the reactions were negative and decreased with the roasting temperature increasing, indicating that all the reactions could be occurred above $573 \mathrm{~K}$. Moreover, it should be noted that the $\Delta G^{\circ}$ values of the reactions (1), (2) and (3) were more negative than that of the other reactions, while the $\Delta G^{\circ}$ value of the reaction (5) was most positive

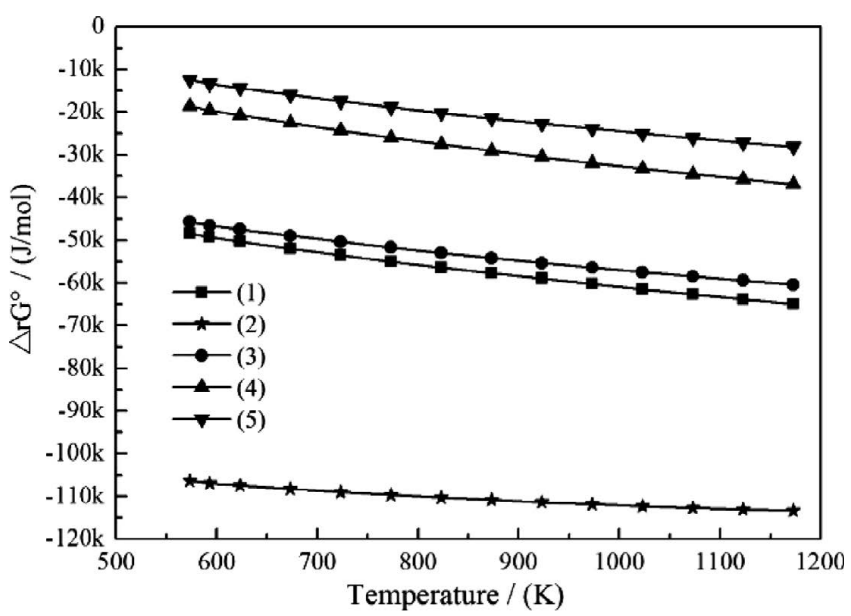

Fig. 4. The plot of $\Delta_{\mathrm{r}} G^{\circ} \sim \mathrm{T}$ for reactions between Ti-bearing EAF slag and molten $\mathrm{NaOH}$.

among all the reactions, suggesting that the Ti-bearing phases in the slag would react with molten $\mathrm{NaOH}$ much earlier than other phases, especially the impurity phase $\mathrm{MgAl}_{2} \mathrm{O}_{4}$ during the molten $\mathrm{NaOH}$ treatment process based on thermodynamic calculation. Considering that $\mathrm{MgAl}_{2} \mathrm{O}_{4}$ was difficult to be decomposed by molten $\mathrm{NaOH}$ than other impurity phase, e.g. $\mathrm{CaSiO}_{3}$, so, the investigation on the transformation of the main impurity phases in this paper was only focus on the decomposition of $\mathrm{MgAl}_{2} \mathrm{O}_{4}$ during the molten $\mathrm{NaOH}$ treatment process.

Because $\mathrm{NaOH}$ can be used as an ionized solvent at higher temperature above $623 \mathrm{~K},{ }^{19)}$ it is reasonable to assume that the reactions between Ti-bearing EAF slag and molten $\mathrm{NaOH}$ may be considered as a solid-liquid reaction mechanism. In order to make sure the Ti-bearing phases or other impurity phases in Ti-bearing EAF slag convert to their corresponding sodium salts completely, Ti-bearing EAF slag/ $\mathrm{NaOH}$ mass ratio $\left(\mathrm{R}_{\mathrm{slag} / \mathrm{NaOH}}\right)$ should be controlled at least below 1 according to the material balance calculation. Moreover, excess amount of $\mathrm{NaOH}$ is necessary to maintain the liquidity of the reactants and ensure their sufficient contact areas during the reactions. Based on the aforementioned analysis, all the experiments should be conducted above $673 \mathrm{~K}$ with $\mathrm{R}_{\text {slag } / \mathrm{NaOH}}$ below 1 .

\subsection{The Effect of Roasting Temperature on the Phase Transformation}

The effect of roasting temperature on the Ti-bearing phases transformation was investigated from $773 \mathrm{~K}$ to $973 \mathrm{~K}$ for $1 \mathrm{~h}$. Figure 5 gives the XRD patterns of alkaline fusion slag obtained under different temperatures with $\mathrm{R}_{\text {slag } / \mathrm{NaOH}}$ fixed at $1: 1$. It can be seen that the diffraction peaks of anosovite solid solution and $\mathrm{Mg}_{2} \mathrm{TiO}_{4}$ completely disappeared while strong diffraction peaks of $\mathrm{Na}_{2} \mathrm{TiO}_{3}\left(2 \theta=40.1^{\circ}\right)$ appeared. This case indicated that the anosovite solid solution (Fig. 6(a)) with orthorhombic crystal system was decomposed by molten $\mathrm{NaOH}$ and converted to $\mathrm{Na}_{2} \mathrm{TiO}_{3}$ (Fig. 6(b)) with cubic crystal structure (until cell parameters of $\mathrm{a}=\mathrm{b}=\mathrm{c}=4.49 \AA$, and $\alpha=\beta=\gamma=90^{\circ}$ ). Increasing the temperature to $873 \mathrm{~K}$, a new phase named $\mathrm{NaMO}_{2}(\mathrm{M}=\mathrm{Ti}, \mathrm{Mg}, \mathrm{Fe})$ with hexagonal crystal system (unit cell parameters of $\mathrm{a}=\mathrm{b}=3.04 \AA$, $\mathrm{c}=16.26 \AA$ and $\alpha=\beta=90^{\circ}, \gamma=120^{\circ}$ ) appeared, which was derived from 


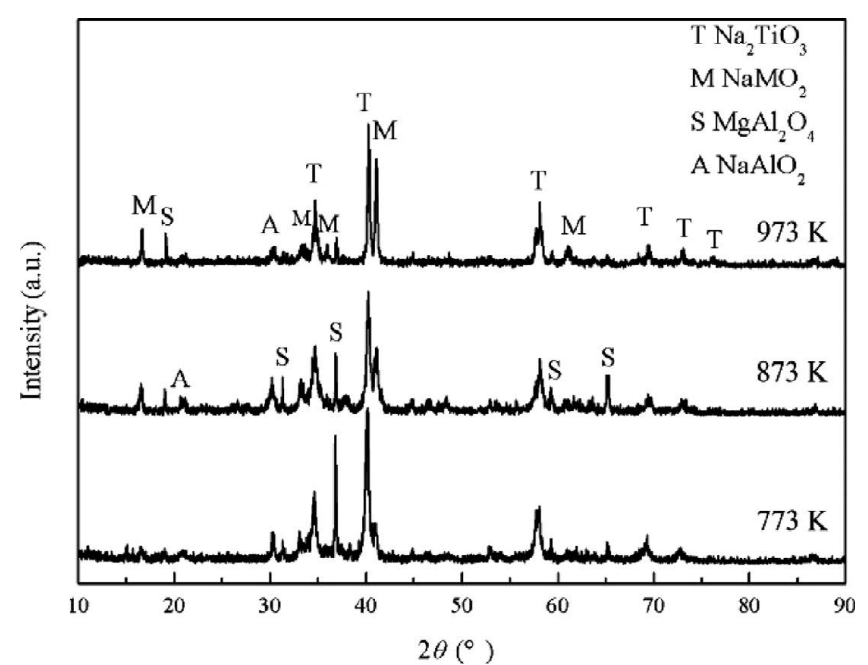

Fig. 5. XRD patterns of alkaline fusion slags obtained under different temperatures with $\mathrm{R}_{\text {slag/ } / \mathrm{NaOH}}$ fixed at $1: 1$.

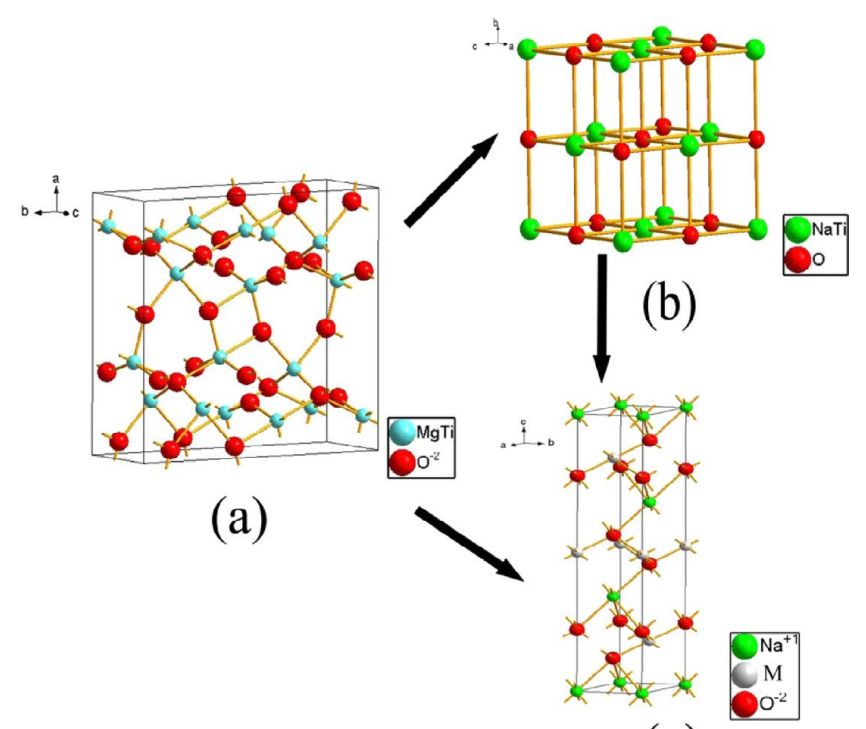

(c)

Fig. 6. The phase transformation relationship between Ti-bearing phases (a) $\mathrm{MgTi}_{2} \mathrm{O}_{5}$, (b) $\mathrm{Na}_{2} \mathrm{TiO}_{3}$, (c) $\mathrm{NaMO}_{2}$. (Online version in color.)

$\alpha-\mathrm{NaFeO}_{2}$-type crystal structure (Fig. 6(c)). ${ }^{14)}$ Further increasing the temperature to $973 \mathrm{~K}$, the diffraction peaks of $\mathrm{NaMO}_{2}\left(2 \theta=16.4^{\circ}, 41.1^{\circ}\right)$ became stronger, whereas the diffraction peaks of $\mathrm{Na}_{2} \mathrm{TiO}_{3}\left(2 \theta=40.1^{\circ}\right)$ turned to weaker, suggesting that relatively higher temperature $(>873 \mathrm{~K})$ may be benefit for Ti-bearing phases (e.g. $\mathrm{MgTi}_{2} \mathrm{O}_{5}$ and $\mathrm{Mg}_{2} \mathrm{TiO}_{4}$ ) transformation to $\mathrm{NaMO}_{2}$ instead of $\mathrm{Na}_{2} \mathrm{TiO}_{3}$ during the molten $\mathrm{NaOH}$ treatment process.

It is known that the compositions of Ti-bearing EAF slag are very complex and various elements including $\mathrm{Fe}^{3+}$ and $\mathrm{Mg}^{2+}$ etc. coexist in the slag system. Therefore, with the roasting temperature increasing, some $\mathrm{Fe}^{3+}$ or $\mathrm{Mg}^{2+}$ ions would be doped into $\mathrm{Na}_{2} \mathrm{TiO}_{3}$, or even substituted the Ti atom of $\mathrm{Na}_{2} \mathrm{TiO}_{3}$ to form a class of layered ionic structure called $\alpha-\mathrm{NaFeO}_{2}$-type crystal structure. ${ }^{14)}$ In this paper, the $\mathrm{M}$ in $\mathrm{NaMO}_{2}$ with $\alpha-\mathrm{NaFeO}_{2}$-type structure phase can be $\mathrm{Fe}, \mathrm{Mg}$ or $\mathrm{Ti}$ elements due to their similar ion radius $\left(\mathrm{Fe}^{3+}=0.064 \mathrm{~nm}, \mathrm{Mg}^{2+}=0.066 \mathrm{~nm}\right.$ and $\left.\mathrm{Ti}^{4+}=0.068 \mathrm{~nm}\right)$. With

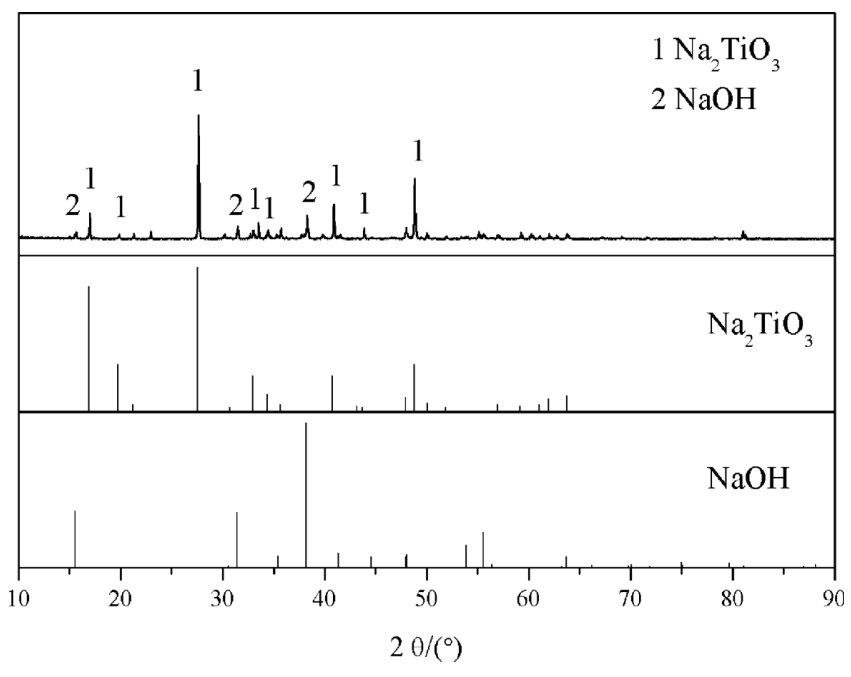

Fig. 7. XRD patterns of the product prepared by pure $\mathrm{TiO}_{2}$ with molten $\mathrm{NaOH}$ at $973 \mathrm{~K}$ for $1 \mathrm{~h}$.

increasing the roasting temperature, more and more $\mathrm{Fe}^{3+}$ or $\mathrm{Mg}^{2+}$ would be doped into $\mathrm{Na}_{2} \mathrm{TiO}_{3}$ to make $\mathrm{Na}_{2} \mathrm{TiO}_{3}$ convert to $\mathrm{NaMO}_{2}\left(\mathrm{M}=\mathrm{Fe}^{3+}, \mathrm{Ti}^{4+}, \mathrm{Mg}^{2+}\right)$, so the amount of $\mathrm{NaMO}_{2}$ increased whereas the amount of $\mathrm{Na}_{2} \mathrm{TiO}_{3}$ decreased. According to the analysis above, nearly all the Ti-bearing phases in Ti-bearing EAF slag could convert to $\mathrm{Na}_{2} \mathrm{TiO}_{3}$ or $\mathrm{NaMO}_{2}$ during the molten $\mathrm{NaOH}$ treatment process, implying the Ti-bearing phase transformation can be realized effectively as illustrated in Fig. 6.

Based on the experimental results, one problem need to be elucidated clearly, that is to say, $\mathrm{Fe}^{3+}$ or $\mathrm{Mg}^{2+}$ doping into $\mathrm{Na}_{2} \mathrm{TiO}_{3}$ would promote $\mathrm{Na}_{2} \mathrm{TiO}_{3}$ to be transformed to $\mathrm{NaMO}_{2}\left(\mathrm{M}=\mathrm{Fe}^{3+}, \mathrm{Ti}^{4+}, \mathrm{Mg}^{2+}\right)$. In order to confirm the key influence factors on the phase transformation between $\mathrm{Na}_{2} \mathrm{TiO}_{3}$ and $\mathrm{NaMO}_{2}$, pure $\mathrm{TiO}_{2}$ (anatase, analytical reagent) was used as raw material to react with $\mathrm{NaOH}$. Meanwhile, other experimental conditions were controlled the same as that during molten $\mathrm{NaOH}$ treatment reaction process. Figure 7 shows the XRD patterns of the product obtained at $973 \mathrm{~K}$ for $1 \mathrm{~h}$. It can be seen that the main phases of the product were only $\mathrm{Na}_{2} \mathrm{TiO}_{3}$ and excess $\mathrm{NaOH}$. None diffraction peaks of $\mathrm{NaMO}_{2}$ appeared, indicating that $\mathrm{TiO}_{2}$ reacted with molten $\mathrm{NaOH}$ could not be reduced to form $\mathrm{NaTiO}_{2}$ in air atmosphere.

However, as shown in Fig. 5, when Ti-bearing EAF slag was used as raw material to react with molten $\mathrm{NaOH}$, the diffraction peaks of $\mathrm{NaMO}_{2}$ did exist at $873 \mathrm{~K}$ and their intensities became stronger with the roasting temperature increasing to $973 \mathrm{~K}$. The results were basically different from each other, suggesting that coexisting elements such as $\mathrm{Fe}^{3+}$ and $\mathrm{Mg}^{2+}$ in the Ti-bearing EAF slag determined the formation of $\mathrm{NaMO}_{2}$ or $\mathrm{Na}_{2} \mathrm{TiO}_{3}$. In order to further investigate the transformation mechanism between $\mathrm{Na}_{2} \mathrm{TiO}_{3}$ and $\mathrm{NaMO}_{2}$, artificially synthesized $\mathrm{MgTi}_{2} \mathrm{O}_{5}$ was used as raw material to react with molten $\mathrm{NaOH}$ under the same experimental conditions. Figure 8 gives the XRD patterns of the products obtained under different roasting temperatures. It can be clearly seen that the main phases of the product were $\mathrm{Na}_{2} \mathrm{TiO}_{3}$ and $\mathrm{MgO}$ when the temperature was fixed at $773 \mathrm{~K}$, while $\mathrm{NaMO}_{2}$ with $\alpha$ - $\mathrm{NaFeO}_{2}$-type crystal structure appeared when the temperature increased to $973 \mathrm{~K}$. So it is 


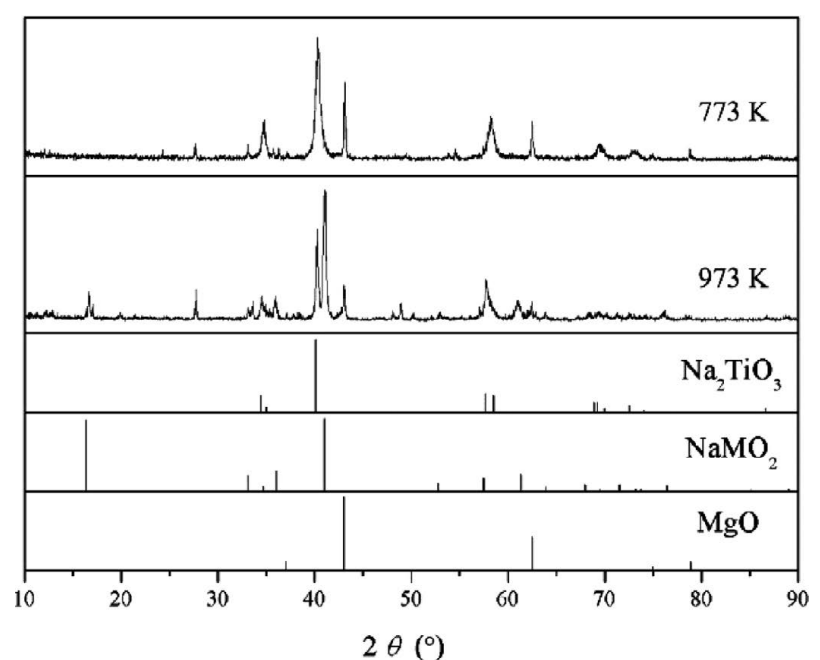

Fig. 8. XRD patterns of the product prepared by artificially synthesized $\mathrm{MgTi}_{2} \mathrm{O}_{5}$ with molten $\mathrm{NaOH}$ under different roasting temperatures for $1 \mathrm{~h}$.

reasonable to assume that the synthesized $\mathrm{MgTi}_{2} \mathrm{O}_{5}$ could be decomposed by molten $\mathrm{NaOH}$ according to the following equations:

$$
\begin{aligned}
& \mathrm{MgTi}_{2} \mathrm{O}_{5}+4 \mathrm{NaOH} \rightarrow 2 \mathrm{Na}_{2} \mathrm{TiO}_{3}+\mathrm{MgO}+2 \mathrm{H}_{2} \mathrm{O} \\
& 673 \mathrm{~K}<\mathrm{T}<773 \mathrm{~K}
\end{aligned}
$$

$$
\begin{aligned}
& \mathrm{MgTi}_{2} \mathrm{O}_{5}+2 \mathrm{NaOH} \rightarrow \\
& 2 \mathrm{Na}\left(\mathrm{Mg}_{1-\mathrm{x}}, \mathrm{Ti}_{\mathrm{x}}\right) \mathrm{O}_{2}+(2 \mathrm{x}-1) \mathrm{MgO}+\mathrm{H}_{2} \mathrm{O} \\
& \mathrm{T}>873 \mathrm{~K}
\end{aligned}
$$

Considering that the $\mathrm{M}$ in $\mathrm{NaMO}_{2}$ is trivalence, it might be assumed that $\mathrm{Ti}^{3+}$ should be formed during the alkali fusion process. It is known that X-ray photoelectron spectroscopy (XPS) is often utilized to detect elements and confirm their corresponding valence state. Figure 9 illustrated the XPS of Ti element in the product obtained at $973 \mathrm{~K}$ for $1 \mathrm{~h}$. The binding energies of the double peaks are $458.1 \mathrm{eV}$ and $463.6 \mathrm{eV}$ for $\mathrm{Ti} 2 \mathrm{p}_{3 / 2}$ and $\mathrm{Ti} 2 \mathrm{p}_{1 / 2}$, respectively. The energy position of this doublet only corresponds to the $\mathrm{Ti}^{4+}$ oxidation state, suggesting that none of $\mathrm{Ti}^{3+}$ existed in the product.

More importantly, from Fig. 8, it also should be noted that both diffraction peaks of $\mathrm{MgO}\left(2 \theta=43.1^{\circ}\right)$ and $\mathrm{Na}_{2} \mathrm{TiO}_{3}$ $\left(2 \theta=40.1^{\circ}\right)$ decreased a lot, while the diffraction peaks of $\mathrm{NaMO}_{2}\left(2 \theta=16.4^{\circ}, 41.1^{\circ}\right)$ increased correspondingly with roasting temperature increasing from $773 \mathrm{~K}$ to $973 \mathrm{~K}$. This phenomenon may be ascribed to that the $\mathrm{Mg}^{2+}$ ionized at relatively high temperature could partially dope into or even substitute the $\mathrm{Ti}$ atom of $\mathrm{Na}_{2} \mathrm{TiO}_{3}$ to form solid solution $\mathrm{Na}\left(\mathrm{Mg}^{2+}, \mathrm{Ti}^{4+}\right) \mathrm{O}_{2}$, that is to say, the apparent trivalence of $\mathrm{M}$ in $\mathrm{NaMO}_{2}$ might be displayed by $\mathrm{Ti}^{4+}$ together with $\mathrm{Mg}^{2+}$. The results agreed well with XRD patterns (Fig. 8) and it can be inferred that higher temperature would be benefit for $\mathrm{Mg}^{2+}$ doping into/substituting the Ti atoms of $\mathrm{Na}_{2} \mathrm{TiO}_{3}$, leading to Ti-bearing phase transformation from $\mathrm{Na}_{2} \mathrm{TiO}_{3}$ to $\mathrm{NaMO}_{2}\left(\mathrm{M}=\mathrm{Mg}^{2+}, \mathrm{Ti}^{4+}\right)$.

In order to verify the assumption, the Raman spectra were used to investigate the change of chemical bonds in the molten $\mathrm{NaOH}$ treatment process. Figure $\mathbf{1 0}$ is the Raman spec-

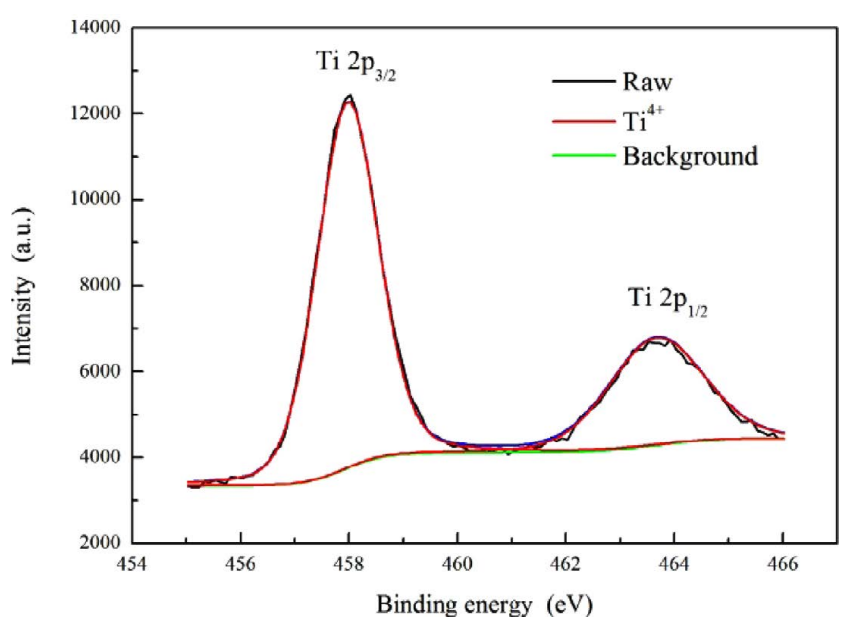

Fig. 9. XPS spectrum of Ti in the alkali fusion slag obtain at $973 \mathrm{~K}$ for $1 \mathrm{~h}$. (Online version in color.)

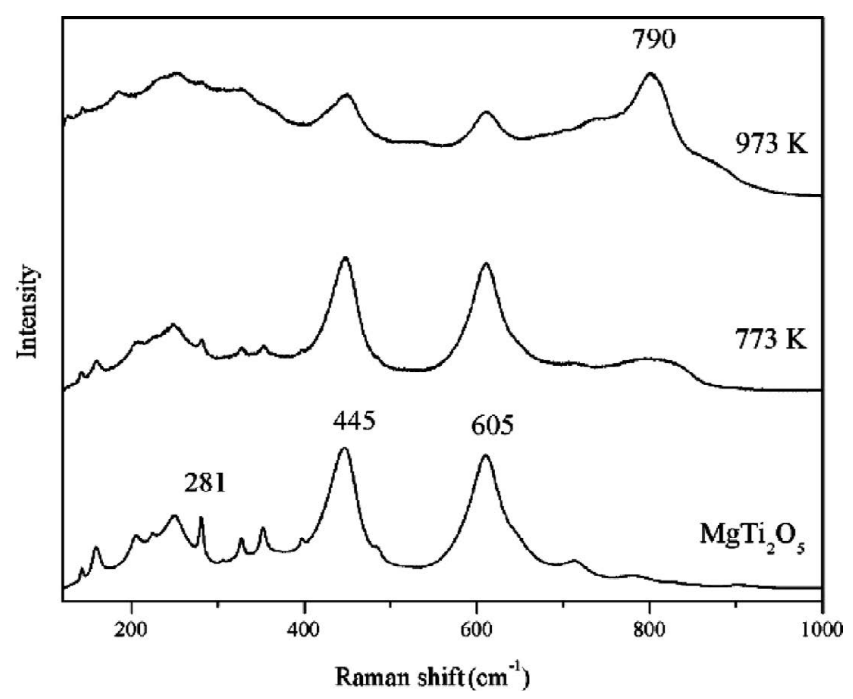

Fig. 10. Raman spectra of $\mathrm{MgTi}_{2} \mathrm{O}_{5}$ and alkali fusion slags obtained under different roasting temperatures for $1 \mathrm{~h}$.

tra of synthesized $\mathrm{MgTi}_{2} \mathrm{O}_{5}$ (Fig. 10(a)) and its corresponding alkali fusion slags obtained under different roasting temperatures (Figs. 10(b) and 10(c)). It can be clearly seen that the Raman spectrum of $\mathrm{MgTi}_{2} \mathrm{O}_{5}$ shows three peaks at 281,445 and $605 \mathrm{~cm}^{-1}$, respectively. Some researchers suggested that the peak near 600 and $445 \mathrm{~cm}^{-1}$ should be ascribed to Ti-O stretching vibrations in 6-coordinated $\mathrm{Ti}^{4+} \cdot{ }^{20,21)}$ Meanwhile, the peaks near $281 \mathrm{~cm}^{-1}$ correspond to the bending and stretching vibration of $\mathrm{Mg}-\mathrm{O}$ bonds. ${ }^{22)}$ When $\mathrm{MgTi}_{2} \mathrm{O}_{5}$ reacted with molten $\mathrm{NaOH}$ at $773 \mathrm{~K}$ for $1 \mathrm{~h}$, the peaks of the alkali fusion slag (Fig. 10(b)) didn't show obvious change comparing to that of $\mathrm{MgTi}_{2} \mathrm{O}_{5}$ (Fig. 10 (a)). However, the intensity of peak at $281 \mathrm{~cm}^{-1}$ decreased a lot, and in the meantime, a weak vibration peak appeared at $800 \mathrm{~cm}^{-1}$ (Fig. 10(b)). This phenomenon may be ascribed to that $\mathrm{Ti}-\mathrm{O}$ band still existed as 6 -coordinated $\mathrm{Ti}^{4+}$ in the obtained $\mathrm{Na}_{2} \mathrm{TiO}_{3}$, but the type of $\mathrm{Mg}-\mathrm{O}$ bonds changed from covalent bond in $\mathrm{MgTi}_{2} \mathrm{O}_{5}$ to ionic bond in $\mathrm{MgO}$, since $\mathrm{MgTi}_{2} \mathrm{O}_{5}$ can be decomposed by molten $\mathrm{NaOH}$ to form $\mathrm{Na}_{2} \mathrm{TiO}_{3}$ and $\mathrm{MgO}$ (Eq. (7)). Further increasing temperature to $973 \mathrm{~K}$, the bending and stretching vibration peaks of $\mathrm{Mg}-$ $\mathrm{O}$ bonds at $281 \mathrm{~cm}^{-1}$ and Ti-O stretching vibration 445 and 


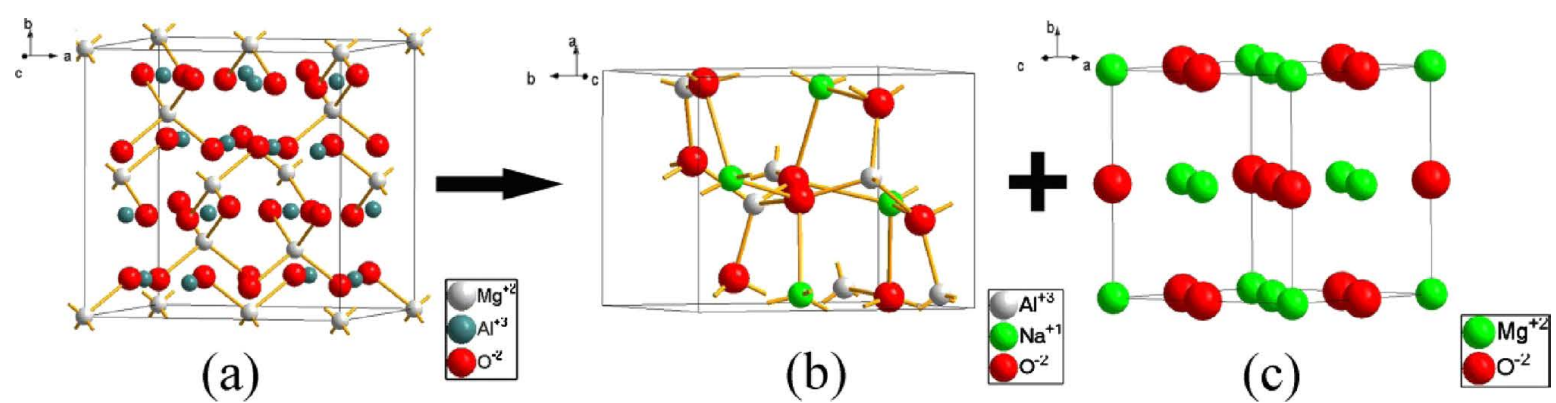

Fig. 11. $\mathrm{MgAl}_{2} \mathrm{O}_{4}$ decomposed by molten $\mathrm{NaOH}$ to form $\mathrm{NaAlO}_{2}$ and $\mathrm{MgO}$. (Online version in color.)

$600 \mathrm{~cm}^{-1}$ disappeared obviously, on the contrary, the intensity of vibration peak at $790 \mathrm{~cm}^{-1}$ increased dramatically (Fig. 10(c)). According to the references, ${ }^{20,23,24)}$ it is known that the vibration peak at $790 \mathrm{~cm}^{-1}$ should be assigned to Ti$\mathrm{O}^{2-}$ stretching vibrations in $\mathrm{TiO}_{4}{ }^{4-}$ tetrahedral monomers. As a result of $\mathrm{Mg}^{2+}$ intercalating into Ti-O bonds, titanyl bond did not exist as 6-coordinated $\mathrm{Ti}^{4+}$, but demonstrated as $\mathrm{Ti}-\mathrm{O}^{2-}$ in $\mathrm{TiO}_{4}{ }^{4-}$ tetrahedral monomers, which combined together to form $\mathrm{O}-\mathrm{Ti}-\mathrm{O}$ or $\mathrm{O}-(\mathrm{Mg}, \mathrm{Ti})-\mathrm{O}$ chain units. According to the analysis of the Raman spectra, it is reasonable to conclude that $\mathrm{MgTi}_{2} \mathrm{O}_{5}$ can be decomposed by molten $\mathrm{NaOH}$ to form 6-coordinated $\mathrm{Ti}^{4+}$ and $\mathrm{Mg}^{2+}$ at $773 \mathrm{~K}$. Then they combined with $\mathrm{Na}^{+}$and $\mathrm{O}^{2-}$ supplied by molten $\mathrm{NaOH}$ to form $\mathrm{NaTiO}_{3}$ and $\mathrm{MgO}$, respectively. However, as the reaction temperature increased to $973 \mathrm{~K}$, some $\mathrm{Mg}^{2+}$ would become ionized state and insert into Ti-O bonds, which made 6-coordinated $\mathrm{Ti}^{4+}$ tetrahedron become to $\mathrm{TiO}_{4}{ }^{4-}$ tetrahedral monomers and then form $\mathrm{O}-(\mathrm{Mg}, \mathrm{Ti})-\mathrm{O}$ chain units. During this process, the crystal structure of $\mathrm{Na}_{2} \mathrm{TiO}_{3}$ changed from NaCl-type crystal structure system to $\alpha-\mathrm{NaFeO}_{2}$-type crystal structure, further confirming the transformation from $\mathrm{Na}_{2} \mathrm{TiO}_{3}$ to $\mathrm{NaMO}_{2} \quad\left(\mathrm{M}=\mathrm{Mg}^{2+}\right.$ and $\left.\mathrm{Ti}^{4+}\right)$.

In addition, as for the main impurity in Ti-bearing EAF slag (e.g. $\mathrm{MgAl}_{2} \mathrm{O}_{4}$ ), the corresponding phase transformation trend was also shown in Fig. 5. It can be seen that with temperature increasing from $773 \mathrm{~K}$ to $973 \mathrm{~K}$, the intensity of diffraction peaks of $\mathrm{MgAl}_{2} \mathrm{O}_{4}$ decreased obviously, suggesting higher temperature would be benefit for $\mathrm{MgAl}_{2} \mathrm{O}_{4}$ decomposition by molten $\mathrm{NaOH}$ according to the following equation:

$$
\mathrm{MgAl}_{2} \mathrm{O}_{4}+2 \mathrm{NaOH}=2 \mathrm{NaAlO}_{2}+\mathrm{Mg}^{2+}+\mathrm{O}^{2-}+\mathrm{H}_{2} \mathrm{O}
$$

Because $\mathrm{NaOH}$ can be used as an ionized solvent when the reaction temperature is higher than $623 \mathrm{~K}$, it is reasonable to assume that the solid-liquid reaction process between $\mathrm{MgAl}_{2} \mathrm{O}_{4}$ and $\mathrm{NaOH}$ was a diffusion controlled process. ${ }^{18)}$ Moreover, $\mathrm{MgAl}_{2} \mathrm{O}_{4}$ belongs to the cubic crystal system (unit cell parameters are $\mathrm{a}=\mathrm{b}=\mathrm{c}=8.09 \AA$ and $\alpha=\beta=\gamma=90^{\circ}$ ), and it has a relative stable and dense structure since $\mathrm{Al}$ ions uniformly dispersed in $\mathrm{Mg}-\mathrm{O}$ bonds as shown in Fig. 11(a). Therefore, increasing the amount of $\mathrm{NaOH}$ during the molten $\mathrm{NaOH}$ treatment reaction, namely, adjusting $\mathrm{R}_{\text {slag } / \mathrm{NaOH}}$, would lead to complete phase transformation of $\mathrm{MgAl}_{2} \mathrm{O}_{4}$ by molten $\mathrm{NaOH}$ to form $\mathrm{NaAlO}_{2}$ and $\mathrm{MgO}$ as illustrated in Fig. 11.

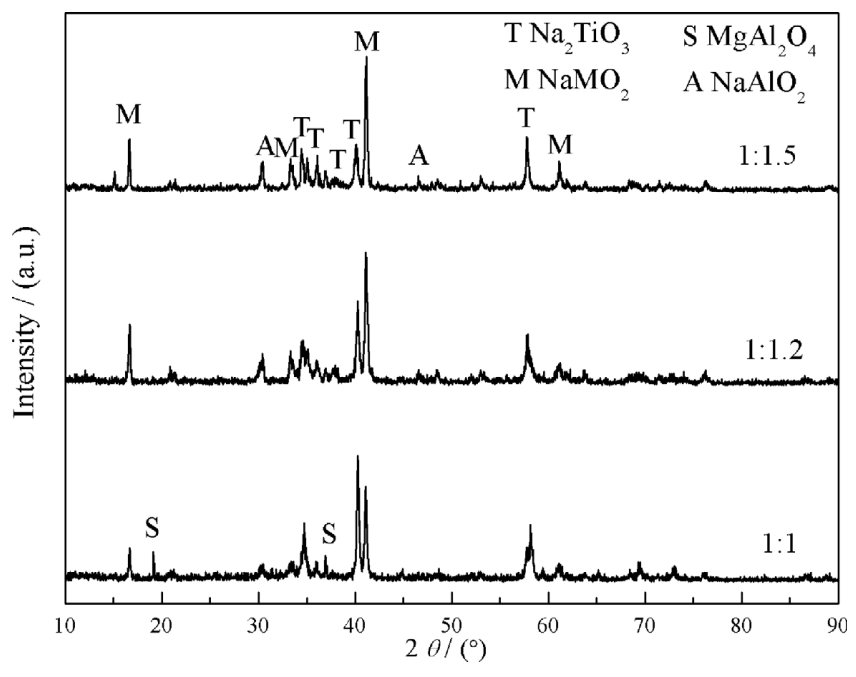

Fig. 12. XRD patterns of alkaline fusion slag obtained at $973 \mathrm{~K}$ for $1 \mathrm{~h}$ with $\mathrm{R}_{\text {slag/ } \mathrm{NaOH}}$ ranging from $1: 1$ to $1: 1.5$.

\subsection{The Effect of Ti-bearing EAF Slag/NaOH Mass Ratio $\left(\mathbf{R}_{\text {slag/NaOH}}\right)$ on the Phase Transformation}

Figure 12 gave the XRD patterns of alkaline fusion slags obtained at $973 \mathrm{~K}$ for $1 \mathrm{~h}$ when $\mathrm{R}_{\text {slag } / \mathrm{NaOH}}$ was controlled from $1: 1$ to $1: 1.5$, respectively. It can be clearly seen that none of the diffraction peaks of anosovite solid solution or $\mathrm{Mg}_{2} \mathrm{TiO}_{4}$ existed in the alkali fusion slags, while some strong diffraction peaks of $\mathrm{Na}_{2} \mathrm{TiO}_{3}$ and $\mathrm{NaMO}_{2}$ appeared accordingly, indicating that all the Ti-bearing phases in Tibearing EAF slag could realize the effective phase transformation even when $\mathrm{R}_{\text {slag } / \mathrm{NaOH}}$ was at $1: 1$. In addition, it is also found that the intensity of diffraction peaks of $\mathrm{MgAl}_{2} \mathrm{O}_{4}$ decreased dramatically when $\mathrm{R}_{\text {slag/ } \mathrm{NaOH}}$ was controlled from $1: 1.2$ to $1: 1.5$ at $973 \mathrm{~K}$. This case may be ascribed to that much more amount of molten $\mathrm{NaOH}$ could ensure sufficient contact areas between reactants (Ti-bearing EAF slag and $\mathrm{NaOH}$ ), leading to $\mathrm{MgAl}_{2} \mathrm{O}_{4}$ complete decomposition under the condition.

More importantly, it should be noted that with $\mathrm{R}_{\text {slag } / \mathrm{NaOH}}$ decreasing from $1: 1$ to $1: 1.5$, the intensities of diffraction peaks of $\mathrm{Na}_{2} \mathrm{TiO}_{3}\left(2 \theta=40.1^{\circ}\right)$ decreased gradually while the intensities of diffraction peaks of $\mathrm{NaMO}_{2}\left(2 \theta=16.4^{\circ}, 41.1^{\circ}\right)$ increased correspondingly, suggesting that some previously formed $\mathrm{Na}_{2} \mathrm{TiO}_{3}$ would be spontaneously converted to $\mathrm{NaMO}_{2}$. This phenomenon may be explained as follows: when the $\mathrm{R}_{\text {slag/ } \mathrm{NaOH}}$ was adjusted from $1: 1$ to $1: 1.5$, according to Eq. (9), almost all $\mathrm{MgAl}_{2} \mathrm{O}_{4}$ in the slag could react with enough molten $\mathrm{NaOH}$, liberating amounts of free $\mathrm{Mg}^{2+}$. In 


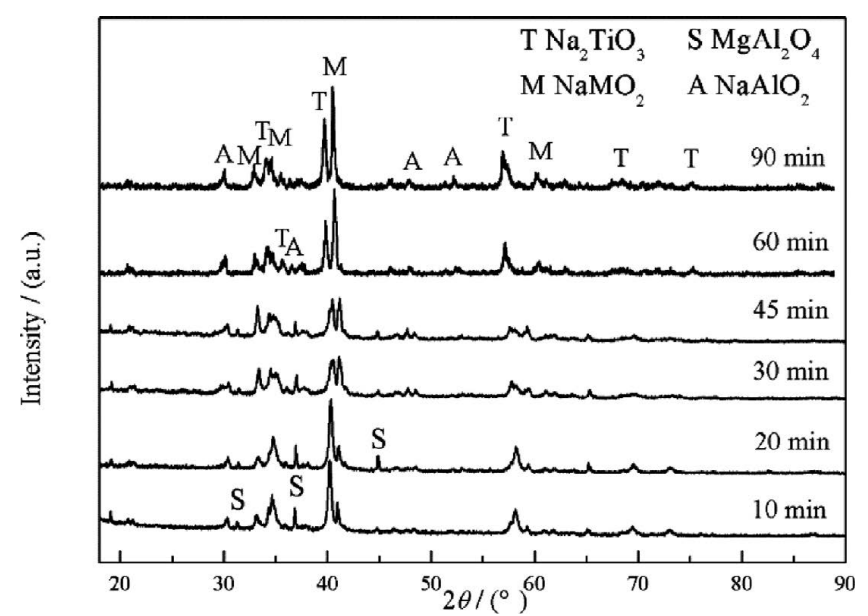

Fig. 13. XRD patterns of alkali fusion slag obtained at $973 \mathrm{~K}$ under different roasting time with $\mathrm{R}_{\text {slag/ } \mathrm{NaOH}}$ fixed at 1:1.2.

the meantime, such free $\mathrm{Mg}^{2+}$ would prefer to dope into/substitute $\mathrm{Ti}$ atoms of $\mathrm{Na}_{2} \mathrm{TiO}_{3}$ to form $\mathrm{NaMO}_{2}\left(\mathrm{M}=\mathrm{Mg}^{2+}, \mathrm{Ti}^{4+}\right)$, rather than combine with $\mathrm{O}^{2-}$ by ionic bond to produce $\mathrm{MgO}$. This result agrees well with XRD patterns as shown in Fig. 12, that is to say, hardly any diffraction peaks of $\mathrm{MgO}$ appeared when $\mathrm{MgAl}_{2} \mathrm{O}_{4}$ was completely decomposed by molten $\mathrm{NaOH}$. In addition, there were obvious diffraction peaks of $\mathrm{NaAlO}_{2}$ existed in XRD patterns, indicating that $\mathrm{Al}$ atoms in $\mathrm{NaAlO}_{2}$ could not be substituted by $\mathrm{Mg}^{2+}$ ion due to their different ionic radius $\left(\mathrm{Mg}^{2+}=0.066 \mathrm{~nm}, \mathrm{Al}^{3+}=\right.$ $0.051 \mathrm{~nm})$.

Based on above analysis, in order to make the main impurity phase $\mathrm{MgAl}_{2} \mathrm{O}_{4}$ convert to water soluble $\mathrm{NaAlO}_{2}$ completely, and then separate from insoluble sodium titanates $\left(\mathrm{Na}_{2} \mathrm{TiO}_{3}\right.$ and $\left.\mathrm{NaMO}_{2}\right)$ by water leaching, excessive amount of $\mathrm{NaOH}$ should be added to maintain a good reaction kinetic condition. Considering the energy consumption and material cost comprehensively, the roasting temperature and $\mathrm{R}_{\text {slag } / \mathrm{NaOH}}$ should be controlled at $973 \mathrm{~K}$ and $1: 1.2$, respectively during the molten $\mathrm{NaOH}$ treatment process.

\subsection{The Effect of Roasting Time on the Phase Trans- formation}

Figure 13 illustrates XRD patterns of alkali fusion slags obtained under different time when roasting temperature was controlled at $973 \mathrm{~K}$ and $\mathrm{R}_{\mathrm{slag} / \mathrm{NaOH}}$ fixed at $1: 1.2$. It is shown that the diffraction peaks of all the Ti-bearing phases in Ti-bearing EAF slag (anosovite solid solution and $\mathrm{Mg}_{2} \mathrm{TiO}_{4}$ ) disappeared just within $10 \mathrm{~min}$. Meanwhile, obvious diffraction peaks of corresponding sodium titanates $\left(\mathrm{Na}_{2} \mathrm{TiO}_{3}\right.$ and $\left.\mathrm{NaMO}_{2}\right)$ emerged, suggesting that all the Tibearing phases in Ti-bearing EAF slag could be converted to sodium titanates $\left(\mathrm{Na}_{2} \mathrm{TiO}_{3}\right.$ and $\left.\mathrm{NaMO}_{2}\right)$ promptly at the initial stage. Moreover, with prolonging the roasting time from 10 to $45 \mathrm{~min}$, the intensities of diffraction peaks of $\mathrm{MgAl}_{2} \mathrm{O}_{4}$ decreased. Furthering increasing the time to 60 or $90 \mathrm{~min}$, nearly all of the diffraction peaks of $\mathrm{MgAl}_{2} \mathrm{O}_{4}$ vanished, implying that relatively longer reaction time (>60 min) would benefit for complete decomposition of $\mathrm{MgAl}_{2} \mathrm{O}_{4}$.

In addition, it is worth noting that the diffraction peaks of $\mathrm{NaMO}_{2}$ with weak intensity appeared within $10 \mathrm{~min}$. When

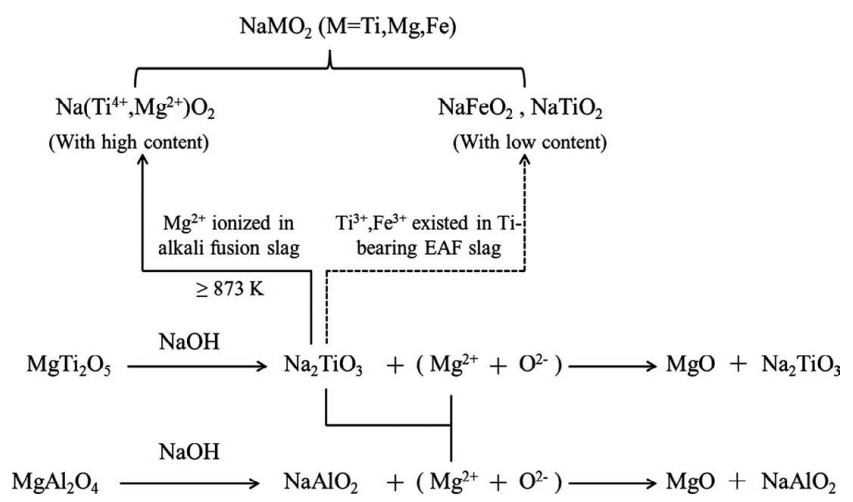

Fig. 14. The schematic diagram of phase transformation during the molten $\mathrm{NaOH}$ treatment process.

the roasting time increased to $30 \mathrm{~min}$ and further to $90 \mathrm{~min}$, the intensity of diffraction peaks of $\mathrm{NaMO}_{2}$ increased gradually whereas that of $\mathrm{Na}_{2} \mathrm{TiO}_{3}$ decreased, and finally, even $\mathrm{NaMO}_{2}$ became the main phase in the alkali fusion slag as shown in Fig. 13. The same phenomenon also appeared when the alkali fusion process was conducted at different roasting temperatures and $\mathrm{R}_{\text {slag } / \mathrm{NaOH}}$. According to the above analysis, it is believed that some trivalence or divalent metal ion like $\mathrm{Fe}^{3+}$ or $\mathrm{Mg}^{2+}$ existed in Ti-bearing EAF slag could dope into/substitute the Ti atoms of $\mathrm{Na}_{2} \mathrm{TiO}_{3}$ to form $\mathrm{NaMO}_{2}$ $(\mathrm{M}=\mathrm{Ti}, \mathrm{Fe}, \mathrm{Mg})$ due to their similar ionic radius $\left(\mathrm{Fe}^{3+}=\right.$ $0.064 \mathrm{~nm}, \mathrm{Mg}^{2+}=0.066 \mathrm{~nm}$ and $\left.\mathrm{Ti}^{4+}=0.068 \mathrm{~nm}\right)$. Therefore, $\mathrm{NaMO}_{2}\left(\mathrm{NaFeO}_{2}, \mathrm{Na}\left(\mathrm{Mg}^{2+}, \mathrm{Ti}^{4+}\right) \mathrm{O}_{2}\right)$ appeared within $10 \mathrm{~min}$ should be ascribed to the doped of these metal ions with low content from Ti-bearing EAF slag. With increasing of roasting time, more $\mathrm{MgAl}_{2} \mathrm{O}_{4}$ was decomposed to liberate more $\mathrm{Mg}^{2+}$, therefore enhanced the chance of $\mathrm{Mg}^{2+}$ doping into/ substituting the Ti atoms of $\mathrm{Na}_{2} \mathrm{TiO}_{3}$ to form solid solution $\mathrm{Na}\left(\mathrm{Mg}^{2+}, \mathrm{Ti}^{4+}\right) \mathrm{O}_{2}$. By this way, the amount of $\mathrm{Na}_{2} \mathrm{TiO}_{3}$ decreased while $\mathrm{NaMO}_{2}$ increased with roasting time pronging.

Based on the aforementioned analysis, the phase transformation mechanism during the alkali fusion process can be illustrated as Fig. 14. It is shown clearly that the main Tibearing phases and impurity phases in Ti-bearing EAF slag can be decomposed by $\mathrm{NaOH}$ to form their corresponding sodium salts. Meanwhile, some cations may dope into/ substitute the Ti atoms of $\mathrm{Na}_{2} \mathrm{TiO}_{3}$ to form $\mathrm{NaMO}_{2}(\mathrm{M}=\mathrm{Ti}$, $\mathrm{Fe}, \mathrm{Mg}$ ) due to their similar ionic radius. During the doping or substitution process, these cations originated from two sources. One is existing in the initial Ti-bearing EAF slag such as $\mathrm{Fe}^{3+}$ or $\mathrm{Ti}^{3+}$, which occupied a small fraction. The other $\left(\mathrm{Mg}^{2+}\right)$ is from decomposition of $\mathrm{MgTi}_{2} \mathrm{O}_{5}$ or $\mathrm{MgAl}_{2} \mathrm{O}_{4}$ by $\mathrm{NaOH}$ with ionic state at high temperature (>873 K), which occupied high content.

\section{Conclusion}

The present work shows that the Ti-bearing phases and the main impurity phases in Ti-bearing EAF slag can realize phase transformation effectively in molten $\mathrm{NaOH}$ fusion process. The phase transformation mechanism was studied systematically by thermodynamic calculation and crystal structure analysis. It is indicated that the Ti-bearing phases in Ti-bearing EAF slag can be decomposed by molten 
$\mathrm{NaOH}$ much earlier and easier than the main impurity phase $\mathrm{MgAl}_{2} \mathrm{O}_{4}$. The Ti-bearing phases transformed from anosovite solid solution or $\mathrm{Mg}_{2} \mathrm{TiO}_{4}$ to $\mathrm{Na}_{2} \mathrm{TiO}_{3}$ with $\mathrm{NaCl}$-type crystal structure easily when the alkali fusion process was above $773 \mathrm{~K}$ with Ti-bearing EAF slag/ $\mathrm{NaOH}$ mass ratio ( $\left.\mathrm{R}_{\text {slag } / \mathrm{NaOH}}\right)$ below $1: 1$. However, the main impurity phase $\mathrm{MgAl}_{2} \mathrm{O}_{4}$ could not be decomposed by molten $\mathrm{NaOH}$ to form $\mathrm{NaAlO}_{2}$ and $\mathrm{MgO}$ completely until the alkali fusion reactions were conducted at $973 \mathrm{~K}$ for $1 \mathrm{~h}$ with $\mathrm{R}_{\text {slag } / \mathrm{NaOH}}$ below 1:1.2. In addition, with increasing roasting temperature and time or decreasing $\mathrm{R}_{\mathrm{slag} / \mathrm{NaOH}}$, the formed $\mathrm{Na}_{2} \mathrm{TiO}_{3}$ with $\mathrm{NaCl}$-type crystal structure could convert to $\mathrm{NaMO}_{2}$ $(\mathrm{M}=\mathrm{Mg}, \mathrm{Ti}, \mathrm{Fe})$ with $\alpha-\mathrm{NaFeO}_{2}$-type crystal structure, due to that some metal ions like $\mathrm{Mg}^{2+}$ or $\mathrm{Fe}^{3+}$ might dope into/ substitute the Ti atoms of $\mathrm{Na}_{2} \mathrm{TiO}_{3}$ to form $\mathrm{NaMO}_{2}(\mathrm{M}=\mathrm{Ti}$, $\mathrm{Fe}, \mathrm{Mg})$.

\section{Acknowledgement}

The work was financially supported by the National Natural Science Foundation of China (Nos. 51372019, 51072022 and 50874013), the National Basic Research Program of China (No. 2014CB643401).

\section{REFERENCES}

1) X. Lei and X. Xue: Trans. Nonferr. Metal. Soc., 20 (2010), 2294.

2) S. Zhang and M. J. Nicol: Hydrometallurgy, 103 (2010), 196.

3) N. El-Hazek, T. A. Lasheen, R. El-Sheikh and S. A. Zaki: Hydrometallurgy, 87 (2007), 45.

4) A. J. Manhique, W. W. Focke and C. Madivate: Hydrometallurgy, 109 (2011), 230

5) Y. Han, T. Sun, J. Li, T. Qi, L. Wang and J. Qu: Int. J. Min. Met.
Mater., 19 (2012), 205.

6) T. Tao, Q. Cen, H. Hu, Z. Yin and Y. Chen: Trans. Nonferr. Metal. Soc., 22 (2012), 1232.

7) L. Zhang, L. N. Zhang, M. Y. Wang, T. P. Lou, Z. T. Sui and J. S. Jang: J. Non-Cryst. Solids, 352 (2006), 123.

8) L. Zhang, L. N. Zhang, M. Y. Wang, G. Q. Li and Z. T. Sui: J. NonCryst. Solids, 353 (2007), 2214.

9) X. F. Lei and X. X. Xue: Mater. Sci. Semicon. Proc., 11 (2008), 117.

10) Z. Z. Guo, T. P. Lou, L. Zhang, L. N. Zhang and Z. T. Sui: Acta Metall. Sin. (English Letters), 20 (2007), 9.

11) M. Y. Wang, Y. H. He, X. W. Wang, T. P. Lou and Z. T. Sui: Trans. Nonferr. Metal. Soc., 17 (2007), 584.

12) Y. Zhang, T. Qi and Y. Zhang: Hydrometallurgy, 96 (2009), 52.

13) S. Middlemas, Z. Z. Fang and P. Fan: Hydrometallurgy, 131-132 (2013), 107.

14) S. J. Clarke, A. J. Fowkes, A. Harrison, R. M. Ibberson and M. J. Rosseinsky: Chem. Mater., 10 (1998), 372.

15) M. Shao-Yu, R. Xiao-Xia and Z. Zhao-Hui: Chinese J. Struc. Chem., 27 (2008), 553.

16) I. M. El-Naggar, E. A. Mowafy, I. M. Ali and H. F. Aly: Adsorption, 8 (2002), 225.

17) W. Antony Hill, A. R. Moon and G. Higginbotham: J. Am. Ceram. Soc., 68 (1985), 266

18) Y. Li, Z. Que, M. Zhang and M. Guo: Int. J. Min. Met. Mater., 20 (2013), 1012.

19) T. Xue, L. Wang, T. Qi, J. Chu, J. Qu and C. Liu: Hydrometallurgy, 95 (2009), 22.

20) K. Zheng, J. Liao, X. Wang and Z. Zhang: J. Non-Cryst. Solids, 376 (2013), 209.

21) L. S. Zhao, Y. H. Liu, L. Wang, H. X. Zhao, D. S. Chen, B. N. Zhong, J. C. Wang and T. Qi: Ind. Eng. Chem. Res., 53 (2014), 70.

22) K. Ishikawa, N. Fujima and H. Komura: J. Appl. Phys., 58 (1985), 973.

23) A. Q. Jiang, G. H. Li and L. D. Zhang: Solid State Commun., 104 (1997), 709.

24) B. Mysen and D. Neuville: Geochim. Cosmochim. Acta, 59 (1995), 325.

\section{Appendices}

Table A1. Thermodynamic data.

\begin{tabular}{|c|c|c|c|c|}
\hline Composition & $\begin{array}{c}\Delta H_{298}^{\circ} \\
(\mathrm{J} / \mathrm{mol})\end{array}$ & $\begin{array}{c}S_{298}^{\circ} \\
(\mathrm{J} / \mathrm{mol} \mathrm{K})\end{array}$ & $C_{p}(\mathrm{~J} / \mathrm{mol} \mathrm{K})$ & $\mathrm{T}(\mathrm{K})$ \\
\hline $\mathrm{MgTi}_{2} \mathrm{O}_{5}$ & -2504887 & 137.34 & $232.58-5660800 \mathrm{~T}^{-2}-755.50 \mathrm{~T}^{-1 / 2}+5.8 * 10^{8} \mathrm{~T}^{-3}$ & $298-1930$ \\
\hline $\mathrm{Ti}_{3} \mathrm{O}_{5}$ & -2452465 & 157.62 & $158.99+5.02 * 10^{-2} \mathrm{~T}$ & $298-1991$ \\
\hline $\mathrm{Mg}_{2} \mathrm{TiO}_{4}$ & -2156788 & 115.10 & $226.11-1701100 \mathrm{~T}^{-2}-1380.10 \mathrm{~T}^{-1 / 2}+41280000 \mathrm{~T}^{-3}$ & $298-2029$ \\
\hline $\mathrm{NaOH}(\mathrm{S})$ & -425931 & 64.44 & $74.57-0.13 \mathrm{~T}+2.55^{*} 10^{-4} \mathrm{~T}^{2}$ & $298-573$ \\
\hline $\mathrm{NaOH}(\mathrm{L})$ & -413211 & 86.32 & $167.64-2.90 \mathrm{~T}-1824129.7 \mathrm{~T}^{-2}+35363.80 \mathrm{~T}^{-1}-2929.24 \mathrm{~T}^{-1 / 2}$ & $593-2500$ \\
\hline $\mathrm{O}_{2}$ & 0 & 205.04 & $26.92+1.70 * 10^{-2} \mathrm{~T}+229329.26 \mathrm{~T}^{-2}-79.161659 \mathrm{~T}^{-1 / 2}$ & $298-1000$ \\
\hline $\mathrm{Na}_{2} \mathrm{TiO}_{3}$ & -1587877 & 121.75 & $198.91-5948599.90 \mathrm{~T}^{-2}-644.30 \mathrm{~T}^{-1 / 2}+8.5^{*} 10^{8} \mathrm{~T}^{-3}$ & $560-1238$ \\
\hline $\mathrm{MgAl}_{2} \mathrm{O}_{4}$ & -2300313 & 84.53 & $235.90-1710415 \mathrm{~T}^{-2}-1766.58 \mathrm{~T}^{-1 / 2}+40616928 \mathrm{~T}^{-3}$ & $298-2381$ \\
\hline $\mathrm{NaAlO}_{2}$ & -1133190 & 70.40 & $89.15+1.53 * 10^{-2} \mathrm{~T}-1793262.4 \mathrm{~T}^{-2}$ & $298-3000$ \\
\hline $\mathrm{MgO}$ & -601500 & 26.95 & $61.11-621154 \mathrm{~T}^{-2}-296.20 \mathrm{~T}^{-1 / 2}+5844612 \mathrm{~T}^{-3}$ & $298-3098$ \\
\hline $\mathrm{CaSiO}_{3}$ & -1634676 & 79.81 & $149.07-3659348 \mathrm{~T}^{-2}-690.29 \mathrm{~T}^{-1 / 2}-4.84 * 10^{8} \mathrm{~T}^{-3}$ & $298-2000$ \\
\hline $\mathrm{Na}_{2} \mathrm{SiO}_{3}$ & -1561430 & 113.85 & $234.77-2218.90 \mathrm{~T}^{-1 / 2}+1.35 * 10^{8} \mathrm{~T}^{-3}$ & $298-1363$ \\
\hline $\mathrm{CaO}$ & -635090 & 37.75 & $58.79-1147146 \mathrm{~T}^{-2}-133.90 \mathrm{~T}^{-1 / 2}+1.03 * 10^{8} \mathrm{~T}^{-3}$ & $298-2845$ \\
\hline $\mathrm{H}_{2} \mathrm{O}$ & -241834 & 188.72 & $25.78+1.49 * 10^{-2} \mathrm{~T}-27999.32 \mathrm{~T}^{-2}$ & $298-1100$ \\
\hline
\end{tabular}

